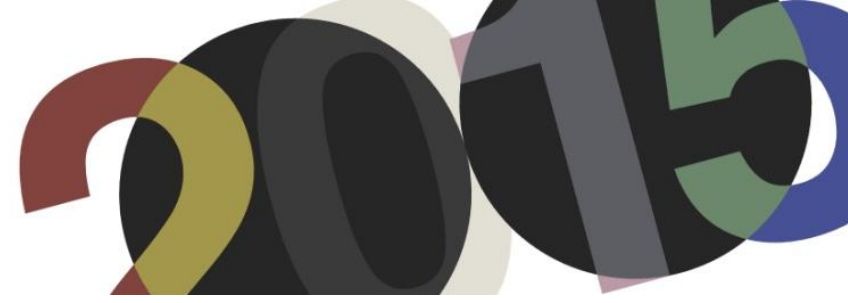

DOI: http://dx.doi.org/10.4995/LC2015.2015.960

\title{
Le Corbusier Roof-Spaces
}

\section{A. Como, I. Forni, L. Smeragliuolo Perrotta}

University of Salerno, Italy

\begin{abstract}
From technical solution, the roof-garden became a key spatial theme within Le Corbusier's work and creativity, evolving to become a fundamental component of his vision for the contemporary city. The roof garden is an open space in which to cultivate both the mind and body, and to experience a direct relationship with nature; through plants, the sky, and the sun, the urban and the natural world are combined together in the surroundings. This article follows the principal steps of Le Corbusier's research, starting with his initial experimentation in his own apartment studio in rue Nungesser-et-Coli, through to the complex development at the Unite. It follows how the roof garden becomes an optical device toward the horizon and a strong evocative instrument. The relationship with the nature and the horizon are the key of readings of several selected design projects which demonstrate at the same time the continuity of the research and the richness of the variations on the theme itself. The roof garden is one of the most fertile topics of Le Corbusier's legacy, evident in contemporary architectural developments.
\end{abstract}

Resumen: A partir de una solución técnica, el roof-garden se convierte en el tema central del trabajo y de la poética de Le Corbusier, evolucionando para convertirse en un componente fundamental de su visión de la ciudad contemporánea. El roofgarden es un espacio abierto en el que el hombre puede cultivar la mente y el cuerpo, donde se puede experimentar una relación directa con la naturaleza -la vegetación, a través de las plantas, el cielo, el sol, el urbano -y el mundo natural se combinan juntos en los alrededores. Este texto sigue los pasos principales de la investigación de Le Corbusier, partiendo de las experimentaciones iniciales -en su apartamento-estudio en la rue Nungesser-et-Coli-hasta el complejo desarrollado en la Unité. El texto sigue como el roof garden se convierte en un dispositivo óptico hacia el horizonte y en un gran instrumento evocativo. La relación con la naturaleza y el horizonte son las claves de lectura de varios proyectos seleccionados que muestran a la vez la continuidad de la investigación y la riqueza de las variaciones sobre el tema. El roof garden es uno de los temas más vivos del legado de Le Corbusier, también de gran importancia hoy en la arquitectura contemporánea.

Keywords: Roof-garden; Nature; View; Horizon; Landscape.

Palabras clave: Roof-garden; Naturaleza; Vista; Horizonte; Paisaje. 


\section{Introduction}

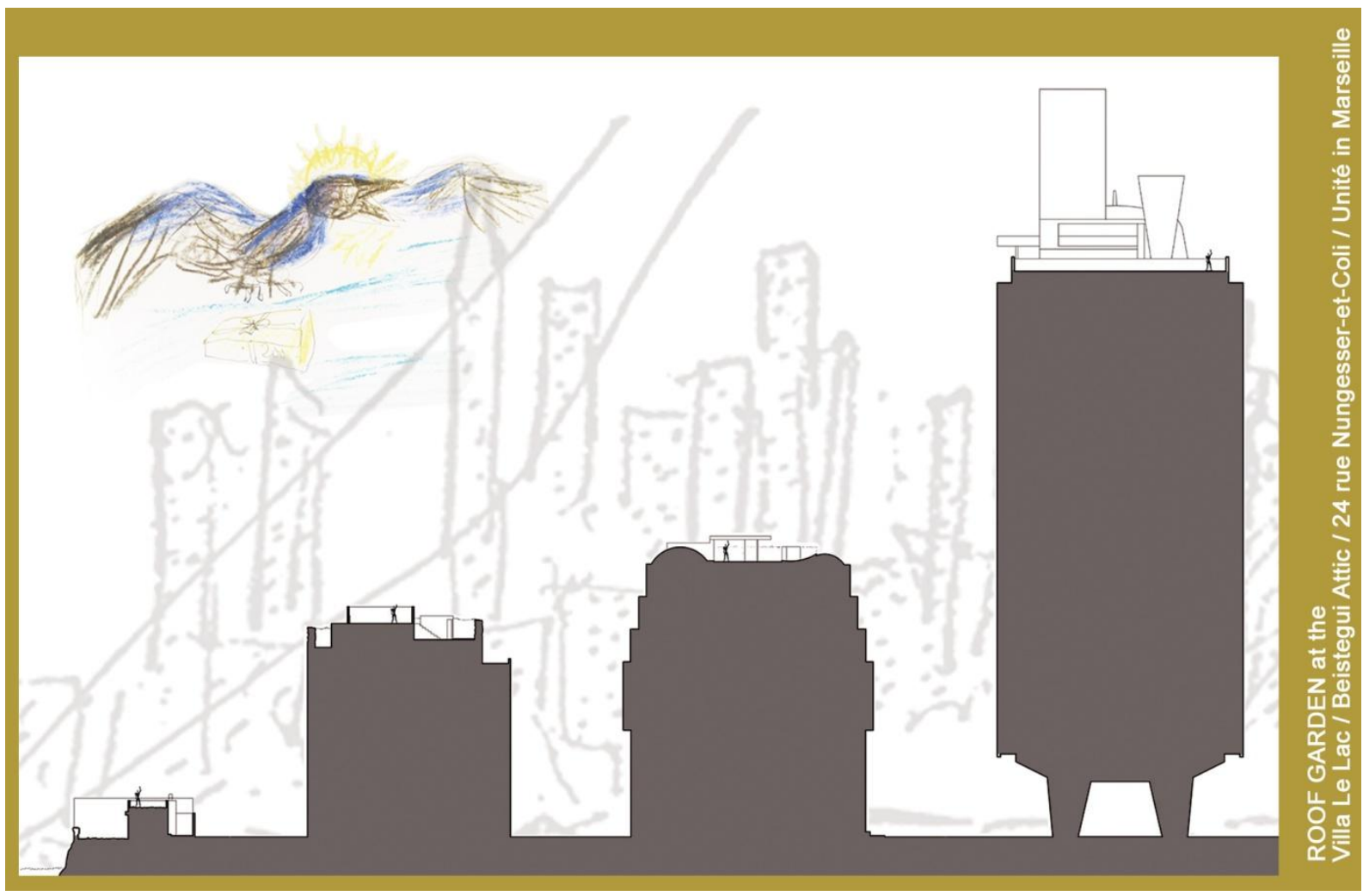

1. Collage by the authors.

Within Le Corbusier research, the roof-garden is not just one of the famous five points of a new architecture, but a totally new and fundamental spatial topic that explores the relationship between architecture and nature. Rather than observing the roof as the crowing element of architecture - a topic which would also involve many ideas and suggestions in Le Corbusier work - this paper examines it as an open-air architectural and urban space in direct connection with the natural world, conceived as an optical device which is focused on the horizon. The roof-garden space is a spatial theme criss-crossing through a variety of projects, a 'fil rouge' which becomes a narrative and interpretative thread throughout his work. Analysing the roof-garden as autonomous form distinct from the building that carries it, one can see the evolution of a theme with continual development and variation through the selected case-studies. The Le Corbusier roof-garden gradually grows both in its dimension and significance, amplifying its relevance and relationships.

Among the four essential functions of the Le Corbusier urbanism - inhabiting, working, circulating, and cultivating the body and the spirit - Le Corbusier assigns the roof-garden the role of responding to the last of these needs. The roof-garden offers a place to enjoy the sun and open-air, to exercise and to contemplate nature and the landscape, either alone or with friends. Nature on the roof-garden is not just an ornament nor frame for the landscape, but is to be physically experienced. The sky, sun and wind, the natural flora, and mountains and sea, are the main characters of Le Corbusier descriptions arising from his personal experience of these elements and forms. Looking from a high up vantage point towards the distant horizon is a leit-motiv connected with his first visual experiences: "All the years of my childhood were spent with my friends amongst nature [...] We were 
always on the mountain peaks; the vast horizon was an everyday view. When the sea of fog below extended to infinity, it looked like the real sea which I had never seen." I
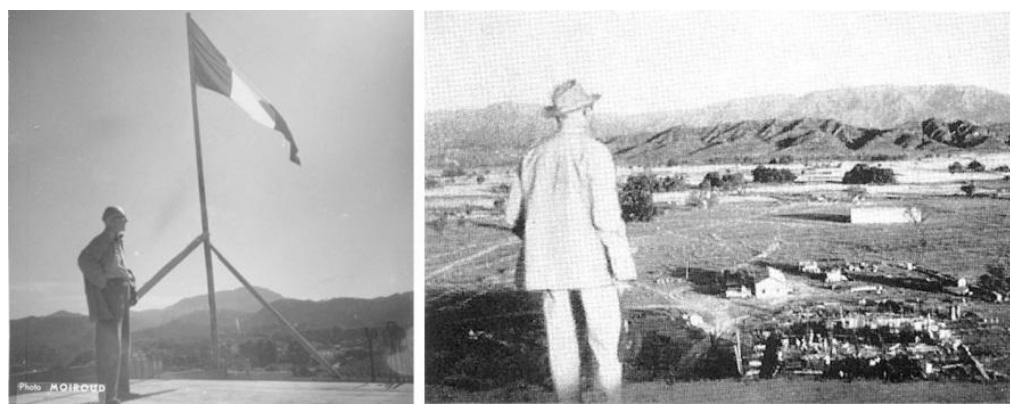

2. a. Le Corbusier on the roof of the Unite d'Habitation in Marseille; b. Le Corbusier on the roof of the Secretariat in Chandigarh.

We will follow Le Corbusier in the act of seeing - through the reading of his texts and visual descriptions, within his design projects and through drawings, film and photography shots. To explain the topic visually, each section of this text is accompanied by a collage, created using Le Corbusier materials. Photographic images have also been selected to communicate conceptual issues rather than provide a comprehensive description of each work. Assembled in sequence, as through a film clip, they show the continuity of the theme within the architectural oeuvre.

We start with the roof-terrace at 24 Nungesser-et-Coli, Paris because Le Corbusier uses it as a case-study in his comment on the roof-garden within the Complete Works. From his own roof-garden an investigation begins on the meaning of nature in the 'natural state' and also involves other projects, such as the Villa Le Lac. The Nungesser-et-Coli roof-garden is also the place where he experiments with visual techniques, testified in Le Corbusier films and photographs. We could consider this experimentation as the basis for future design process, through which he transfers his visual analysis into strategies for composition, crucially involving the horizon and the reshaping of the landscape into a series of scenes. The relationship with nature and the process of selecting a composition of views through the control of the horizon are the two main topics within Le Corbusier roof-garden projects, variously developed in each project. They become the key of reading of our selection of case-studies.

The Beistegui attic, in Paris, focuses on the process of vision. Other design projects, mainly villas, rather than commented in detail, construct a thematic anthology through descriptions and images, conveying the richness of the solutions and the experience of the roof-garden. Then, when designing Marseille Unite roof-garden the process of creating a composite of horizon determined views becomes defined, and in turn shapes the architecture and the open spaces. Le Corbusier's view of the city from the height of his roof-terraces seems to find continuity in the contemporary scenario and he appears, rather than a visionary, an architect capable of visions.

\section{The Roof-Terrace Nature}

Le Corbusier's roof terrace at 24 Nungesser-et-Coli becomes a paradigm, and is included as a case study in Report on a Roof-garden in the Complete Works ${ }^{2}$.

\footnotetext{
${ }^{1}$ Le Corbusier: L'Art décoratif d'aujourd'hui. Paris: G. Crès \& Cie, 1925. Translation by authors.
} 
From a technical point of view Le Corbusier considers the roof-garden as the "model protector of the roof". Technical issues had already been explained within the $1^{\text {st }}$ volume: the flat roof is a consequence of the reinforced concrete construction; a consistent humidity on the roof is ensured by the presence of the earth and plants, decreasing problems of expansion and contraction of the reinforced concrete. Apart from these technical reasons, the roof-garden is an opportunity for recovery of the built-up area. Furthermore, "The city roofs could also become places of poetry". It is therefore a combination of several reasons, involving "technique, economy, comfort, and sentiment", 3 , which lead to development of the roof-garden.

Whilst these are his motivations for adopting the roof-garden theme, what is the garden's essence and how was it established? Rather than being built, it is created from nature itself: "Instead of 'digging my own garden', I let it grow". The photograph of the Nungesser-et-Coli roof-garden illustrates this concept: "A roof-garden established in 1932 on the eight floor of a block of flats in Paris, left in its natural state since 1940: ivy, cythise, lilacs, euonymus, box, plane (false sycamore), dog roses, thuya, lavender, lilies, lilies-of-the-valley, iris, and several bushy plants, grass", says the caption.

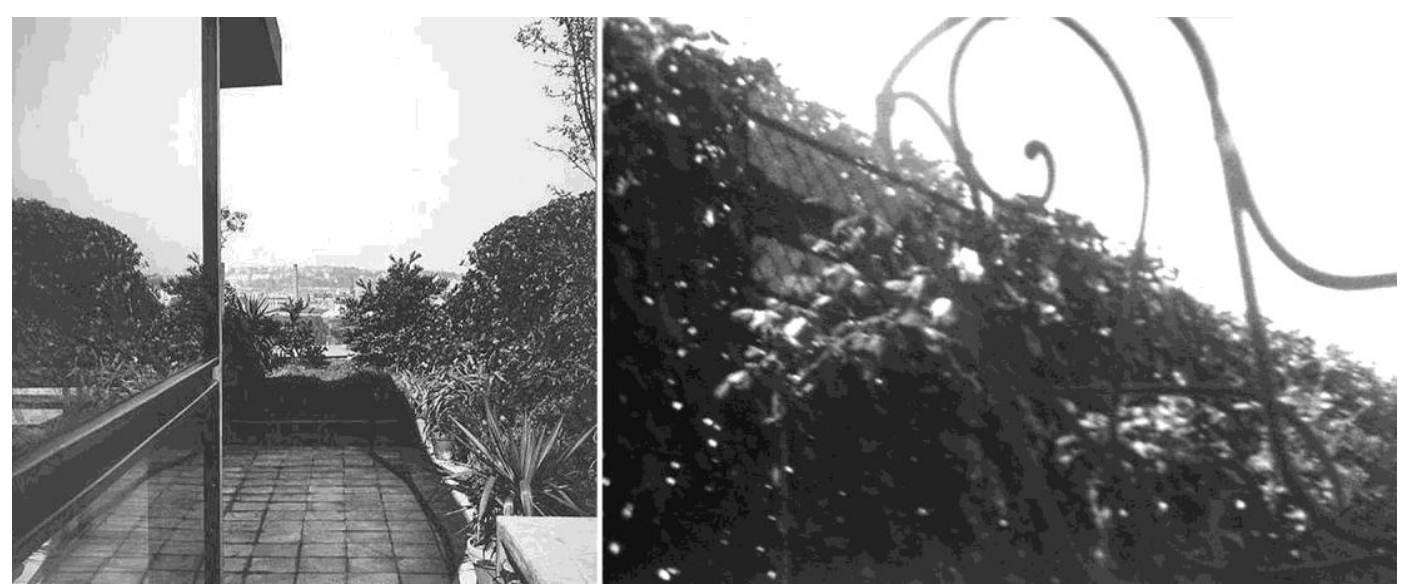

3. Roof-garden at 24 rue Nungesser-et-Coli, Paris.

Le Corbusier follows the idea gained from a head gardener: "Don't worry, let it be, nature will look after it". The roof-garden is the place where nature "regains its rights", where the natural elements are the ones to dictate its development: "The sun rules, the wind (above there) rules". In the Report Le Corbusier describes the sensory aspect of the garden - the power of the sun and of the wind, the beauty of nature. He specifies the plant species of his garden: "The roses have gone wild and become magnificent Eglantines; the lavender twigs have become large bushes. The turf has become long grass; white, pink and yellow clover appear according to the Seasons". Here Le Corbusier rather than a planner becomes an observer; he follows the development of that natural state, the growth of the planted seeds, as well as of those brought by the wind, assisting a continuous evolutionary process. "A sycamore seed arrived on a stormy day: I am watching this latest arrival which threatens to become a giant. A bird brought a cythise seed, and in the spring the dense yellow flowers jostle the near-by lilacs. Ten years ago I planted a sprig of lily-of-the-valley, now a hundreds of lilies-of-the-valley open each first of May".

\footnotetext{
2 "Report on a Roof-Garden". In Le Corbusier: Oeuvre complète 1938-46. Volume 4. Boesiger, Willy (Ed.). Zurich: Girsberger, 1977. 7th ed. p. 140. All the following paragraph notes, unless stated, will refer to the same text.

3 "Les 5 Points d'une Architecture Nouvelle". In Le Corbusier: Oeuvre complète 1910-29. Volume 1. Boesiger, Willy (Ed.). Zurich: Girsberger, 1984. 11th ed. pp. 128-129.
} 
The space on the roof which can be recovered in modern cities, the cities made of reinforced concrete, is therefore a place of nature. Here nature has been separated from architecture, yet they live side by side, each one with its own laws. Le Corbusier gives space to the untamed and to the sensory and physical levels, aspects which are not often highlighted in the literature in his work, but clearly illustrated in his published text and images.

\subsection{The roof space in rue Nungesser-et-Coli}

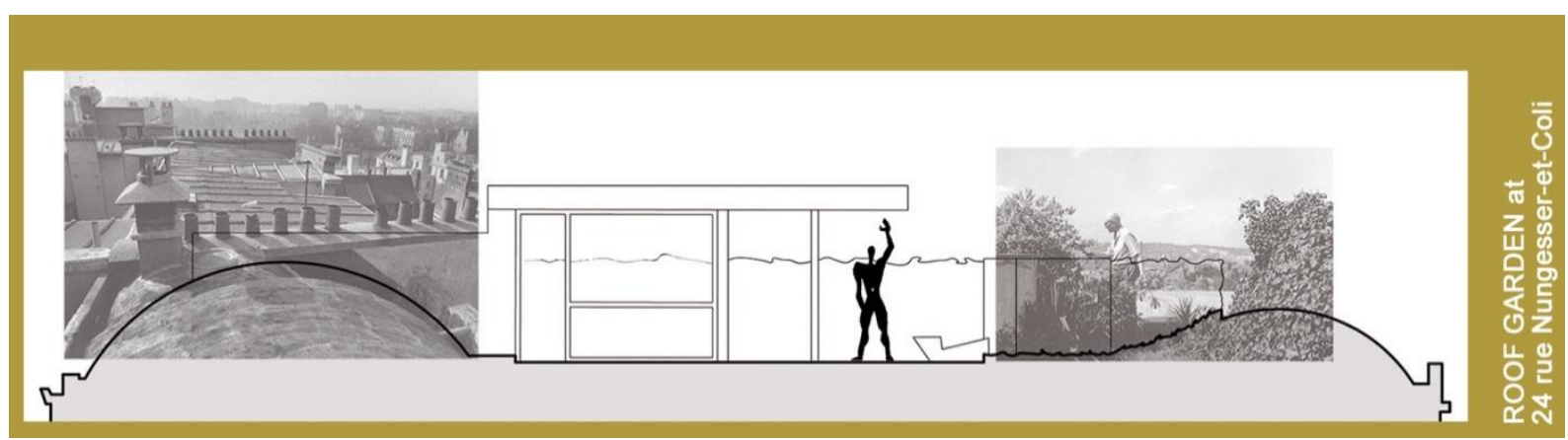

4. Collage by the authors.

The roof-garden at 24 rue Nungesser-et-Coli is the crowning element of the apartment/atelier on the seventh floor of the housing block, designed by Le Corbusier and Pierre Jeanneret between 1931 and 1934 in the Porte Molitor district. The apartment and painting studio occupy the entire seventh floor in open plan; the living area facing west towards the Bois de Boulogne and the area which at the time was countryside around Paris. The studio faced the stadium of Jean-Bouin, towards the east.

One reaches the roof space by a staircase - without a handrail - in plastic form, wrapped around an iron post. The entrance to the terrace is glazed on three sides, like a lantern, and is covered by a reinforced concrete cantilevered slab. From the lower level of the apartment one can see the leaves and the sky. The roof-terrace is a contained space, dominated by vegetation. The boundaries are defined on east and west by the extradoses of the vaults covering the apartment and studio below, and to the north and south by vegetation growing around simple iron espaliers. The plants also grow on earthed areas that partially cover the vault to the east, overhead of the apartment. From the garden one can see the city roofs, the park and the countryside. "You see Paris" is the opening sentence of Report on a Roof Terrace in the Complete Works. A sectional drawing, dated 7 August 1932 (FLC 13413), shows raised spaces designed into the top of the vaults - accessed by metal steps - achieving even higher level vantage points.

Le Corbusier designs both the roof terrace and the apartment through the control of the views and the relationship with the horizon, using some "architectural stratagems" ${ }^{4}$. The curvilinear surfaces of the vaults limit the view of the immediate surrounding, leading the eye towards the far away views. Le Corbusier comments on the sight in a letter to his mother: "Really, it's magnificent. There's a view over the countryside with so sense of being perched up on the 7th or 8th floor, thanks to architectural stratagems. No giddiness that way. The garden a poem. Lawn, lilac, roses, and more, and what a horizon!" 5.

\footnotetext{
${ }^{4}$ Letter by Le Corbusier to his mother, 29 April 1934. In Cohen, Jean-Louis: Le Corbusier Le Grand. New York: Phaidon Press Limited, 2014. p. 286.

${ }^{5}$ Ibid.
} 


\subsection{Experimentations on the roof space}

In his small roof-terrace of rue Nungesser-et-Coli, Le Corbusier experiments with his ideas about nature and the control of the views. The films made by Le Corbusier in 1936-38 ${ }^{6}$, using professional equipment ${ }^{7}$, contain selected frames and photographs of these years, and include sequences filmed at his apartment and its roof garden. One sequence filmed from the apartment balcony, starts from the paving below, then rises up along the plane of the shelf from where the city appears, framed in a pan that shows a progression from the urban towards the park and the surrounding countryside. The edge of the balcony parapet becomes the horizontal plane that defines from where the landscape is read.

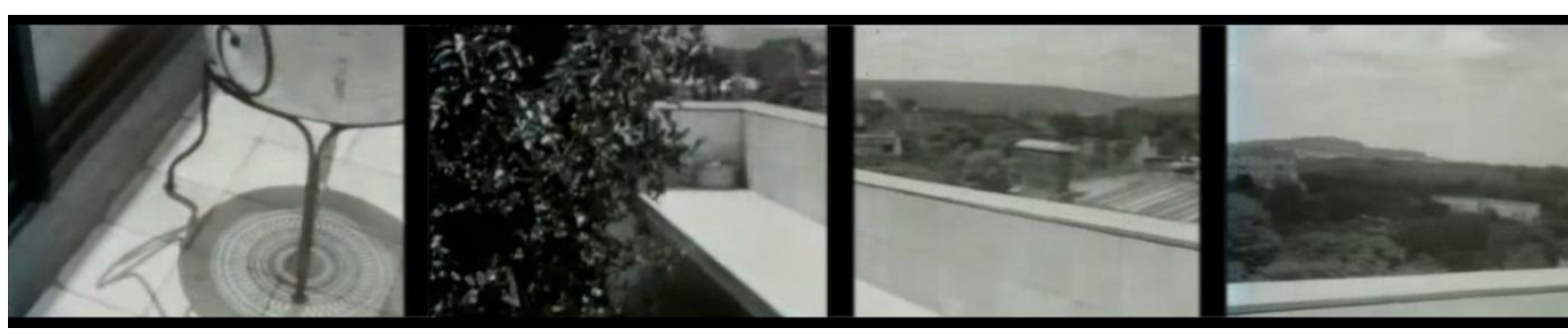

5. Stills from Le Corbusier 1936-38 film. Montage by the authors.

Another sequence in this film includes the roof garden. The shots start bottom-up, showing the view of the leaves and the sky from the staircase. When the camera arrives in the roof garden, it stays at a very low height, around the base of the vegetation.

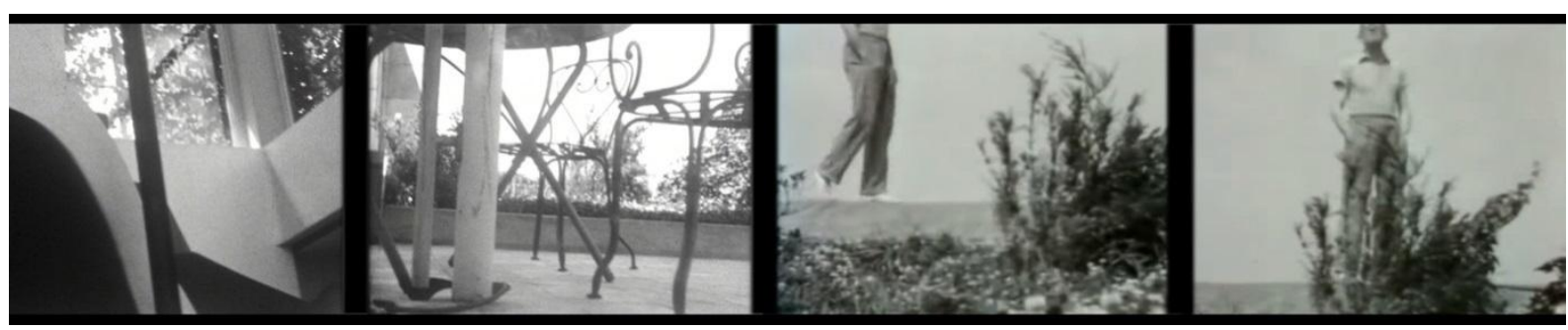

6. Stills from Le Corbusier 1936-38 film. Montage by the authors.

A series of close up frames, show the roof garden plants; consistent in their natural image with Le Corbusier's description of a wild and untamed garden in Report on a Roof-Garden. The vegetation is the main character, initially shown in isolation and then in a relationship with human figures - Le Corbusier, on the curvilinear surface of the vault, and his mother, gardening.

All these images are carefully studied and create a relation among planes: the ground, the upper edge of the vault, the mass of the vegetation. The shots, seen from bottom-up, exalt and even appear to falsify, these dimensional relationships. Le Corbusier films, and the visual frames he creates within the garden, should be considered visual reflections and studies on the landscape. As in his notebook drawings and annotations, Le Corbusier marks down - here at a visual level - the techniques used in connection with landscape and ideas here tested in his own space. Films and photographs, rather describing and representing, become a means of capturing a reflection on landscape issues and suggest spatial architectural solutions to adopt. Le Corbusier experiments with the relationship between the foreground and background, between close and the far, observing the

\footnotetext{
${ }^{6}$ «Films de Le Corbusier» () FLC-ADAGP, Paris: Fondation Le Corbusier.

${ }^{7}$ Benton, Tim: "Le Corbusier Secret Photographer". In Sbriglio, Jacques : Le Corbusier. Aventures photographiques. Paris: Éditions de la Villette, 2014. pp. 46-69.
} 
relationships between masses. He highlights the distant view by cutting out less meaningful parts; he selects views and studies the sequence of planes, depths, and the relationship with light and shadow, thereby creating a sequence of views as a montage. Created within places of his private life, around elements of his personal landscape, these images become a paradigm of his design concepts connected with visual fields and the horizon line.

\subsection{Landscape experimentations at the villa Le Lac}

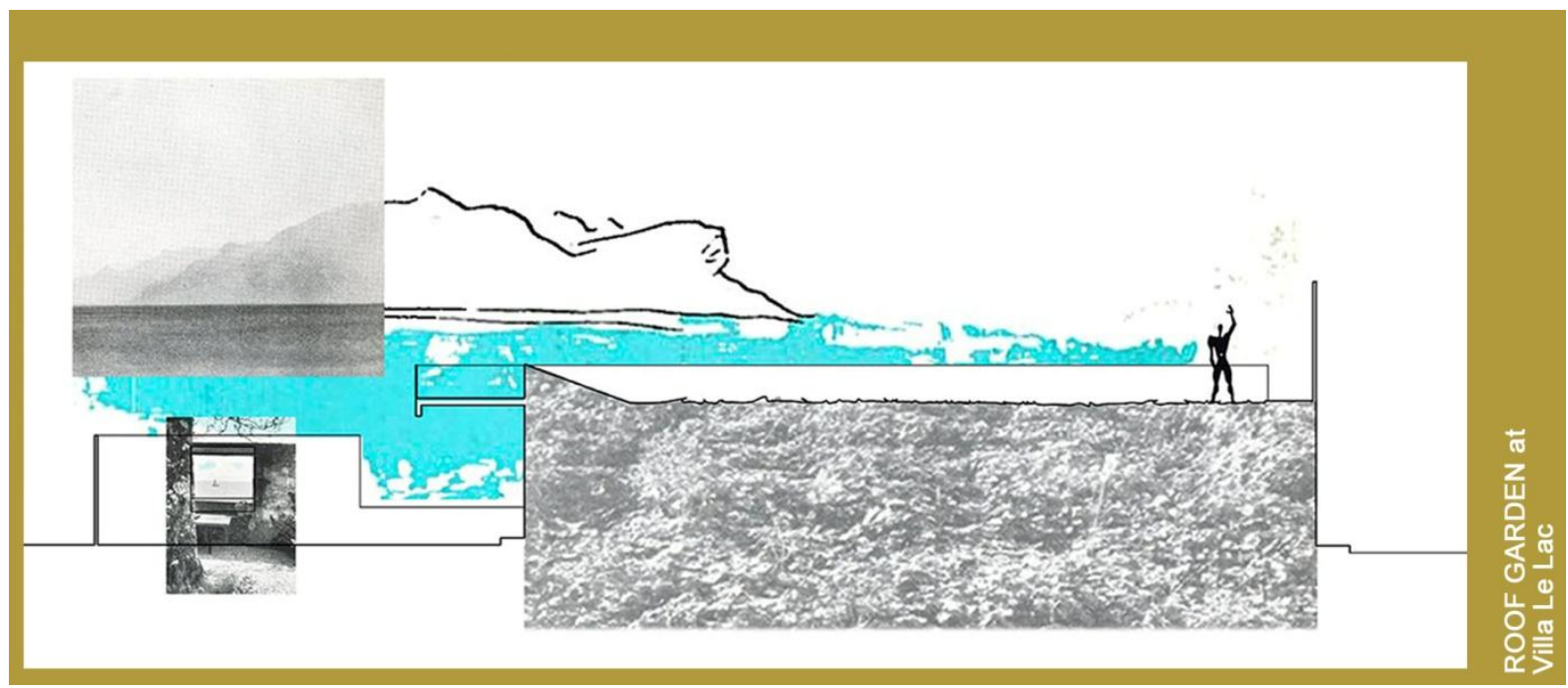

7. Collage by the authors.

As for his apartment in Paris, in the Villa Le Lac, designed for his parents, Le Corbusier realizes photographic and filmic shots ${ }^{8}$ which display similar studies about nature and landscape. The shots go either from the house to the lake or from the lake to the house, revealing a predominant interest on the relationship between architecture and nature. More than the house itself with the interior spaces, the film highlights the open spaces and the surroundings. The attention is focused on the horizon line. The greenery, luxuriant and protagonist of the scenes, is observed both in distance and close by.

In some frames, there is Le Corbusier himself, seated on the parapet along the lake, with the pipe, who seems in the act of explaining the place and the distant views.

The film narrative will be later developed in the form of a text, Une Petite Maison ${ }^{9}$, testifying once again that Le Corbusier camera fixes notes on visual topics. In the book the Villa Le Lac roof is narrated as the arrival of an almost curvilinear route which goes from the street, to the courtyard, to the inside of the house itself, and then outside again. The roof garden, "a pleasure known to some civilizations in former centuries", is a discovery: "here we are on the top!". Both in the film and within the text Le Corbusier constructs a visual plot through a montage of scenes; he modulates anticipations, interests, and surprises, as a cinema director.

\footnotetext{
${ }^{8}$ «Films de Le Corbusier» () FLC-ADAGP, Paris: Fondation Le Corbusier.

9 Le Corbusier: Une Petit Maison 1923. Zurich: Aux Édition d'Architecture, 1954. All following quotes in this sub-section are extracted from this text.
} 


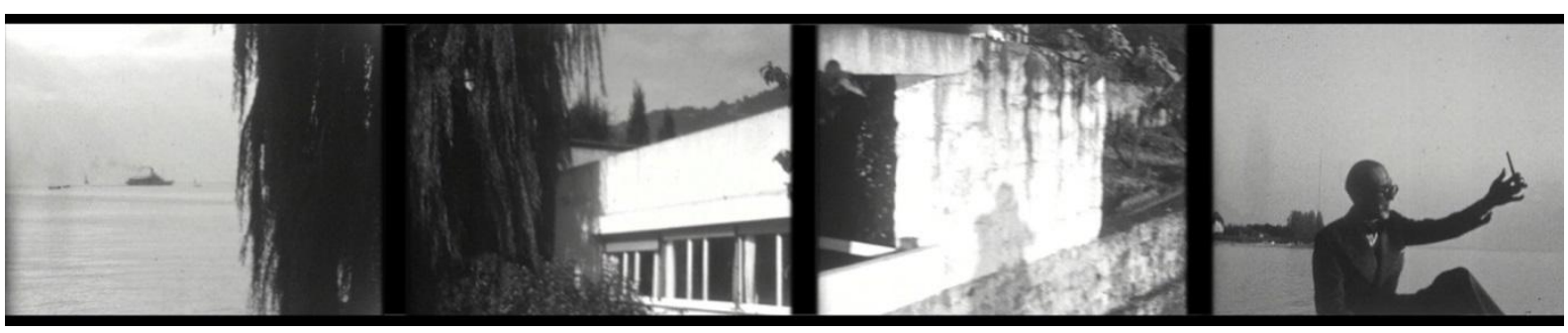

8. Stills from Le Corbusier 1936-38 film. Montage by the authors.

The space of the roof is then described through the same interpretations of the roof garden in rue Nungesser. First it is explained from a technical point of view - the roof garden regulates the temperature - and then it comments on the natural state of the nature. "Pay attention! It is towards the end of September. The autumn flowers are blossoming and the roof is green once more, for a thick carpet of wild geraniums has overgrown everything. It is a wonderful sight. In spring the young grass sprouts up with its wild flowers; in summer it is high and luxuriant. The roof garden lives independently, tended by the sun, the rain, the winds and the birds which bring the seeds. (Latest news, April 1954): the roof is completely blue with forgetme-nots. No one knows how they arrived". The raised view is an extraordinary condition comparable to the sight from the deck of a ship: "Is it a ship's rail or the wall of a roof we are leaning on? (A boat passing on the lake was also shown in the film). While the sight at the lower open spaces is confined by walls or framed by windows, on the roofgarden it finally spreads out on the open horizon.

The roof garden in Villa Le Lac, in particular its character of a place where nature grows according to its natural cycle, is a solution - both technical and suggestive - that recurs in other projects. Through the description on the convent of La Tourette, Le Corbusier highlights the continuity of his research. "The roof of the convent itself, like that of the church, will be covered with a thin layer of earth left to the vicissitudes of the wind, birds and other carriers of seeds, assuring both water-tightness and isothermic protection. (The roofs of the small house on Lake Léman, constructed thirty years ago, the apartment house at 24 Rue Nungesser et Coli and various buildings in India are similarly constructed) ${ }^{, 10}$.

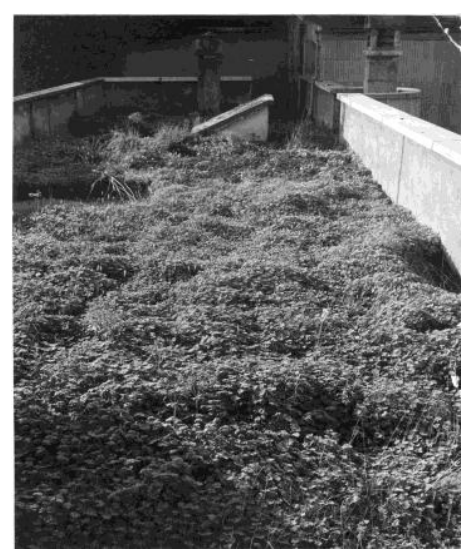

9. Roof-garden at Villa Le Lac.

10 “The Convent of La Tourette”. In Le Corbusier: Oeuvre complète 1952-1957. Volume 6. Boesiger, Willy (Ed.). Zurich: Girsberger, 1985. 7th ed. p.42. 


\section{Screening and Seeing}

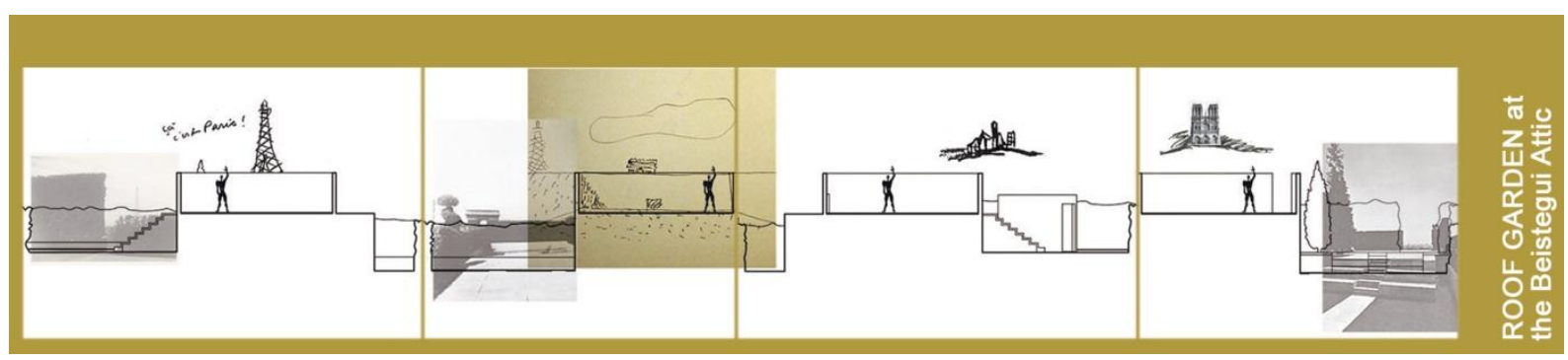

10. Collage by the authors.

Opposite to the Villa Le Lac condition, where the sight is initially enclosed and framed and then it conquers the possibility to space out on the roof, within the Beistegui Attic the view is gradually compressed along the ascending path leading to the solarium, which becomes a room without ceiling.

In a letter addressed to the client, Le Corbusier declares his immense interest in the attic development "because it offers a solution for the roofs of Paris, that I have been talking about 15 years ",l.

With the design project of the Beistegui Attic, Le Corbusier "places Paris on a stage" 12 . The space of the roof captures the landscape, with views cut out through the act of screening. The screens are made of stone or natural walls are created, for example, with an ivy hedge that, through mechanical stratagems, unfolds the view, "revealing Paris" ${ }^{13}$. Within this space so markedly surreal, also nature radically changes becoming, from untamed and natural, now artificially designed and even mechanised and man-made.

"The architectural solution to this problem is, in some way, an act of devotion to Paris. Let us explain: from this belvedere, Paris is visible on all its horizons: both in the most admirable places and in the dark desert of the roofs and the chimneys. The choice was to suppress that panoramic view and to create another architectural centre of stones, gardens and sky, completely isolated from the turbulence of the panorama, and to offer, in precise points, some exciting prospects of four of the things, visible from the place, that make the prestige of Paris: the Arc-de-Triomphe, at point-blank, the Tourre Eiffel, the Sacré-Coeur, and finally the mass of greenery overflowing from the Champs-Elysée to the Tuileires and which falls in the rivers, with Notre-Dame that stands out as an outline on a milky horizon. This concerns the architectural landscape proposed for all the rooms, both interior and exterior, on different terraces built on four successive levels"14.

Designing becomes an operation of selecting within the urban landscape. The Paris which is shown isn't the real city - with the people, the buildings, the streets - but the idea of Paris, the mental construction of the city. Le Corbusier rewrites the city through his selective process.

The Beistegui Attic is composed of a sequence of spaces, following a route from the lower gardens to the white room at the highest level; the sequence builds the city as it flows, like a cinematographic view ${ }^{15}$. By deliberately

\footnotetext{
${ }^{11}$ Tafuri, Manfredo: “ 'Machine et memoire': The City in the Work of Le Corbusier”. Santarelli, Stephen (Trans.). In Brooks, H. Allen (Ed.): Le Corbusier. Princeton: Princeton University Press, 1987. p. 203.

${ }^{12}$ Reichlin, Bruno: “L’Esprit de Paris”. In Casabella. January/February 1987, № 531/532. Milano: Electa. p. 55.

${ }^{13}$ Le Corbusier: "L’Arc-de-Triomphe a bruciapelo". In Casabella, January/February 1987. op. cit. p. 60.

${ }^{14} \mathrm{Ibid}$.

15 “A Geography of the Moving Image". In Bruno, Giuliana: Atlas of Emotion: Journeys in Art, Architecture, and Film. New York: Verso Books, 2007. pp. 55-71.
} 
controlling and restricting elements of the view, the architectural space opens up at different levels to reveal different parts of the city.

"The fourth terrace is a few steps further above: it encircles the building: we pass the steps and arrive at a door made of a stone slab: this door slowly opens and shows a completely white ambient, entirely carpeted with a grassy cloak. The door closes again: it is the silence. You don't see any other that the sky and the play of the clouds and the patch of blue; it is a sensation of breath, of open ocean. Near the grassy carpet, a fireplace to light a fire, during the coolest evenings. [...] Only a yew breaks a corner of sky" ${ }^{\prime \prime}$.

The visual path over the city of Paris is set up in the first three levels of the roof-garden and culminates in the last terrace: the solarium, an open-air room. Contrasting with the experience in lower levels, the space here has no stones, only a synthetic grass carpet enclosed by high walls enveloping the space within an intimate and surreal atmosphere. Here silence and introspection prevail, together with the detachment from the city. The Paris spectacle, selected and mise-in-scene by the architect at the lower levels of the garden, becomes even more selective at the solarium level. Standing on the attic one sees hardly anything of the city. The experience is all in the privileged contact among man, sky and the grass cloak covering the paving. "The city is banished from the sight in the highest terrace, and hence receives the highest tribute to the limit" ${ }^{17}$.

\section{The experience of the roof-garden}

Le Corbusier experiments with a variety of spatial conditions for the roof garden: it can be an elevated space with vegetation within the heart of the building; it can be a terraced garden, external to the building; it can be a solarium, at the top. For some projects Le Corbusier proposes a sequence of roof gardens, at different levels or terraces, which create new spatial and visual relations. The relationship with nature and the landscape, which are the main topics, is developed in a variety of ways. The roof walls cut the views on the city and frame landscape portions; in other cases, the nature enters into the composition as a scene.

Besides the different spatial conditions characterising the roof garden, there are common themes, illustrated through our selection of photographs and anthology of descriptive texts, in order to convey the experience of the Le Corbusier roof garden. Read in succession, these extracts in our montage of texts and images narrate the space of the roof in Le Corbusier work. "This villa has a story"18.

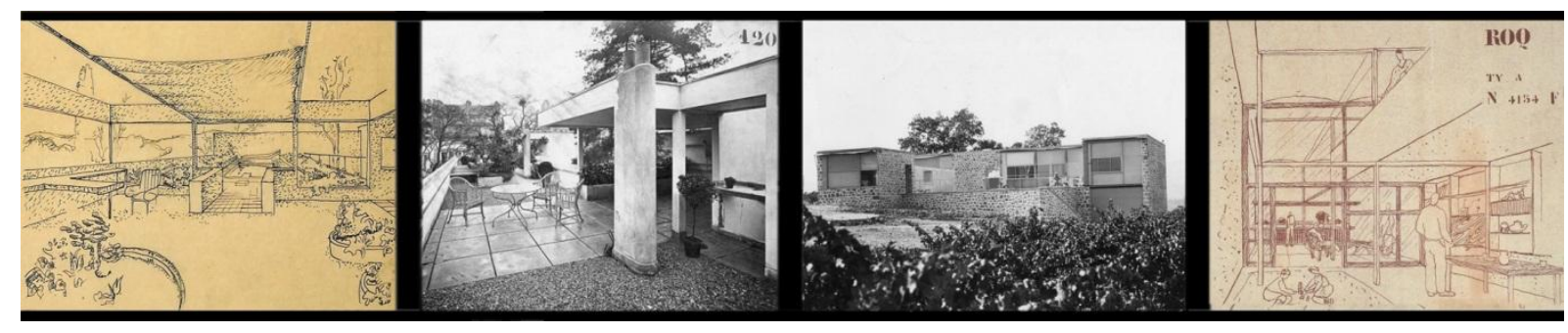

11. a. Villa Meyer; b. Maison La Roche; c. Villa de $\mathrm{M}^{\mathrm{me}}$ H. De Mandrot; d. Roq et Rob.

From a technical point of view by "establishing the garden on the roof, one protects the concrete slabs from expansion during summer. During winter, the garden insulates from the cold. The garden is the logic

\footnotetext{
${ }^{16}$ Le Corbusier: "L'Arc-de-Triomphe a bruciapelo". op. cit. p. 61.

${ }_{17}^{17}$ Reichlin, Bruno: 'L'Esprit de Paris". op.cit. p. 55. Authors' translation.

18 "Villa Shodhan", incipit description. In Le Corbusier: Oeuvre complète 1952-1957. Volume 6. op. cit. p.134.
} 
complement of the flat roof" ${ }^{19}$, the roof-garden becomes "...an authentic architectural event, carrier of charme and poetry, a magnificent free luxury ${ }^{, 20}$.

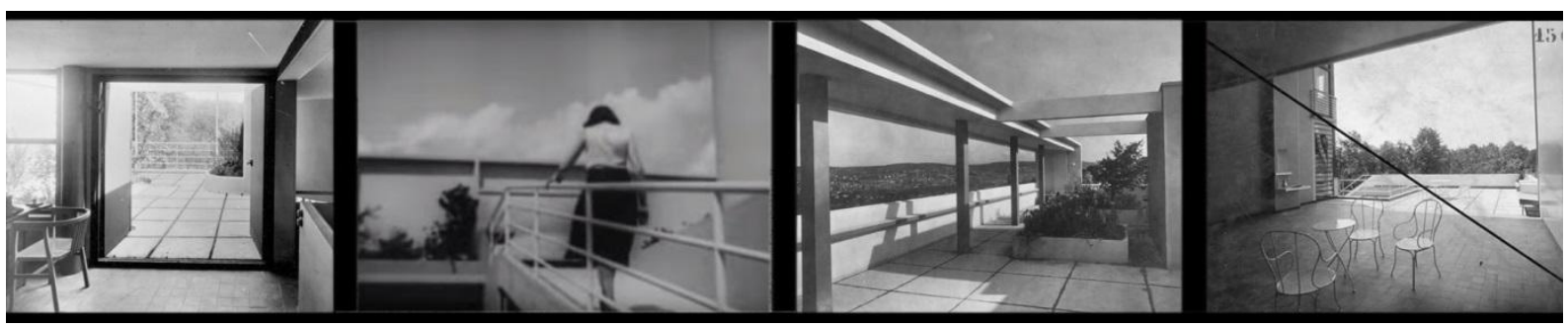

12. a. Maison Cook; b. Ville Savoye; c. Maisons Weissenhof; d. Villa Stein.

From the elevated space of the roof garden, there's a new relationship with the city. "The entrance is at the top of the house. One goes directly on the roof-garden from where one dominates the vast plantation of the Bois de Boulogne: one is no longer in Paris, it is like being in the country"21.

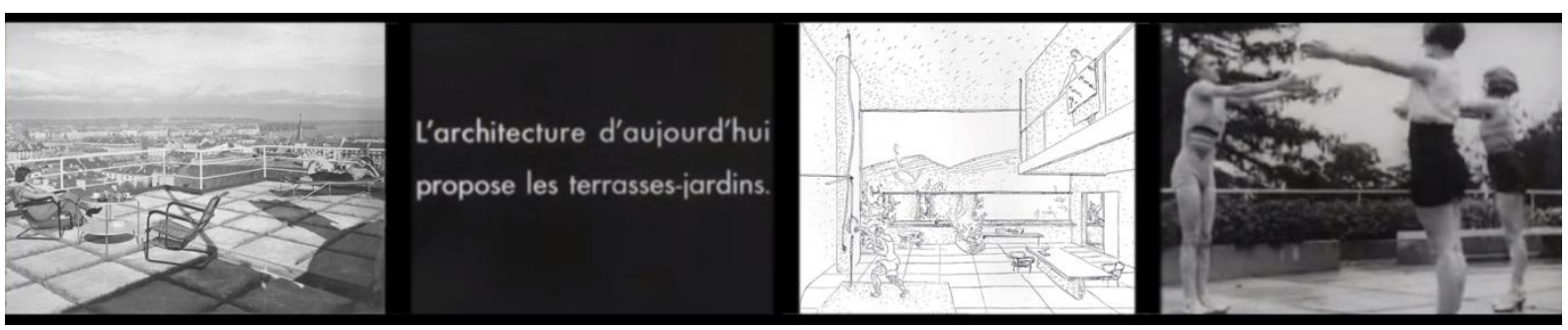

13. a. Immeuble Clarté; b. frame by Architecture d'aujourd'hui; c. Immeuble Wanner; d. Ville d'Avray.

At a short distance but at the same time quite far away, the city can be contemplated from a new vantage point. "From the boudoir you go out onto the roof, where there are no tiles, no slates, but instead a solarium and a swimming pool, with grass growing between the paving stones. Above is the sky: The walls mean that nobody roundabout can see you. In the evening you see the stars and the dark shape of the Folie St- James. Sliding screens offer total privacy. [...]This isn't a classic French garden, but a wild copse where, thanks to the woodland of the Parc St-James, you'd think you're miles from Paris",22.

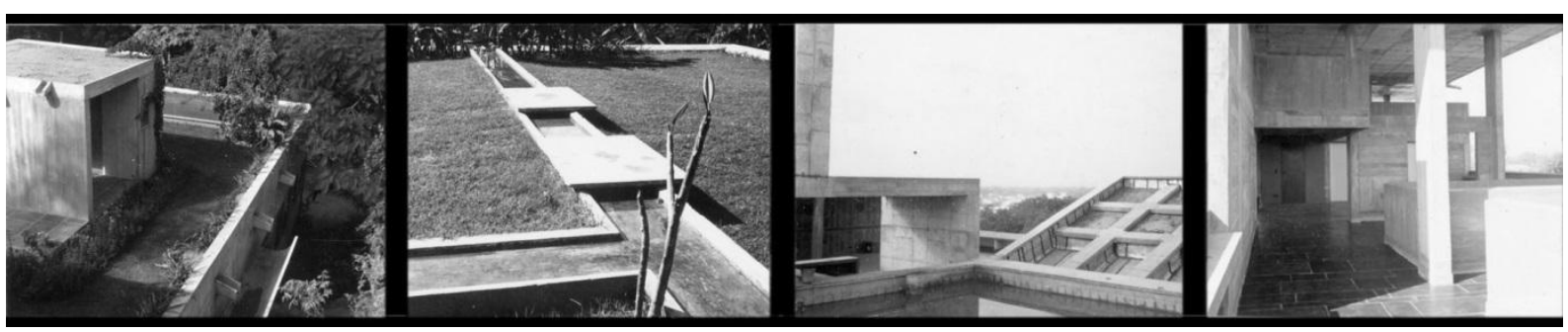

14. a. and b. Villa Sarabhai; c. Ahmedabad Millowners; d. Villa Shodhan.

Nature therefore becomes an essential element of the roof-garden and the surrounding landscape, integral to its composition: "The composition is organised through the landscape. The house occupies a small promontory

\footnotetext{
19 “Villa à Garches”. In Le Corbusier: Oeuvre complète 1910-1929. Volume 1. op. cit. p.145.

20 "Deux Maison construites pour la Ville de Stuttgart dans la colonie de Weissenhot". In Le Corbusier: Oeuvre complète 1910-1929. Volume 1. op. cit. p.150.

21 "Petit hotel particulier à Boulogne-Sur-Seine (Cook) 1926". In Le Corbusier: Oeuvre complète 1910-1929. Volume 1. op. cit. p.130. Authors' translation.

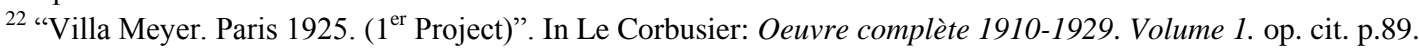


overlooking the plane behind Toulon, which is closed off by the beautiful outline of the mountains [...] it is forerun by a suspended garden which serves as first level and which links the habitation to the Pavilion reserved for the friends" ${ }^{23}$. The roof-garden is the place of socialisation: "the roof is used together with the bar for evening entertainment" ${ }^{\prime 24}$. The privileged contact with nature also makes the roof-garden an ideal place to take care of the body: "A bit of exercise before departing to the city. The pavilion is a bit further in the park: architecture and nature are mutually enhanced $d^{25}$.

Architecture and nature merge in the space of the roof-garden: "Grass sprouts out among the joints of the slabs; some snails move quietly; some tree were planted: tujas, cypresses, charcoals, okubas, China laurels, privet, tamarindas, etc. Six years have passed, the greenery is more beautiful than in any garden: the roof-garden is a bit like the conditions of a greenhouse (because the air is pure, the light intense, and the roots are in a hot and humid soil). The owner of the house said this spring: 'Come and see my lilac on my roof; it has more than one hundred of flowers bunches!' Family life takes place in the upper part of the house"26.

The succession of roof-gardens at different levels creates a new architectural space with a continuous landscape: "Above, the accommodations are disposed in the space of a "hanging garden", on several levels, constituting three apartments, separate and yet in contact with one another" ${ }^{27}$.

\footnotetext{
23 “"Villa de $\mathrm{M}^{\mathrm{me}} \mathrm{H}$. De Mandrot, 1930-31”. In Le Corbusier: Oeuvre complète 1929-34. Volume 2. Boesiger, Willy (Ed.). Zurich: Girsberger, 1984, p.59.

24 “Ahmedabad Millowners' Association Building Ahmedabad 1954”. In Le Corbusier: Oeuvre complète 1952-1957. Volume 6. op. cit. p. 144.

${ }^{25}$ Decription text of Ville d'Avray extracted from the film Architecture d'Aujourd'hui. Directed by Pierre Chenal. Script by Pierre Chenal and Le Corbusier. Texts by Le Corbusier. Music by Albert Jeanneret. Produced by the review Architecture d'Aujourd'hui, $35 \mathrm{~mm}$, b\&w, time $18 \mathrm{~min}$. 1930. Translation by the authors.

26 “Maison La Roche - Janneret 1923. Le Jardin sur le toit”. In Le Corbusier: Oeuvre complète 1910-1929. Volume 1, op. cit. p.65. Translation by the authors.

27 "Villa Shodhan". op. cit.
} 


\section{The stone roof-garden of the Unité of Marseille}

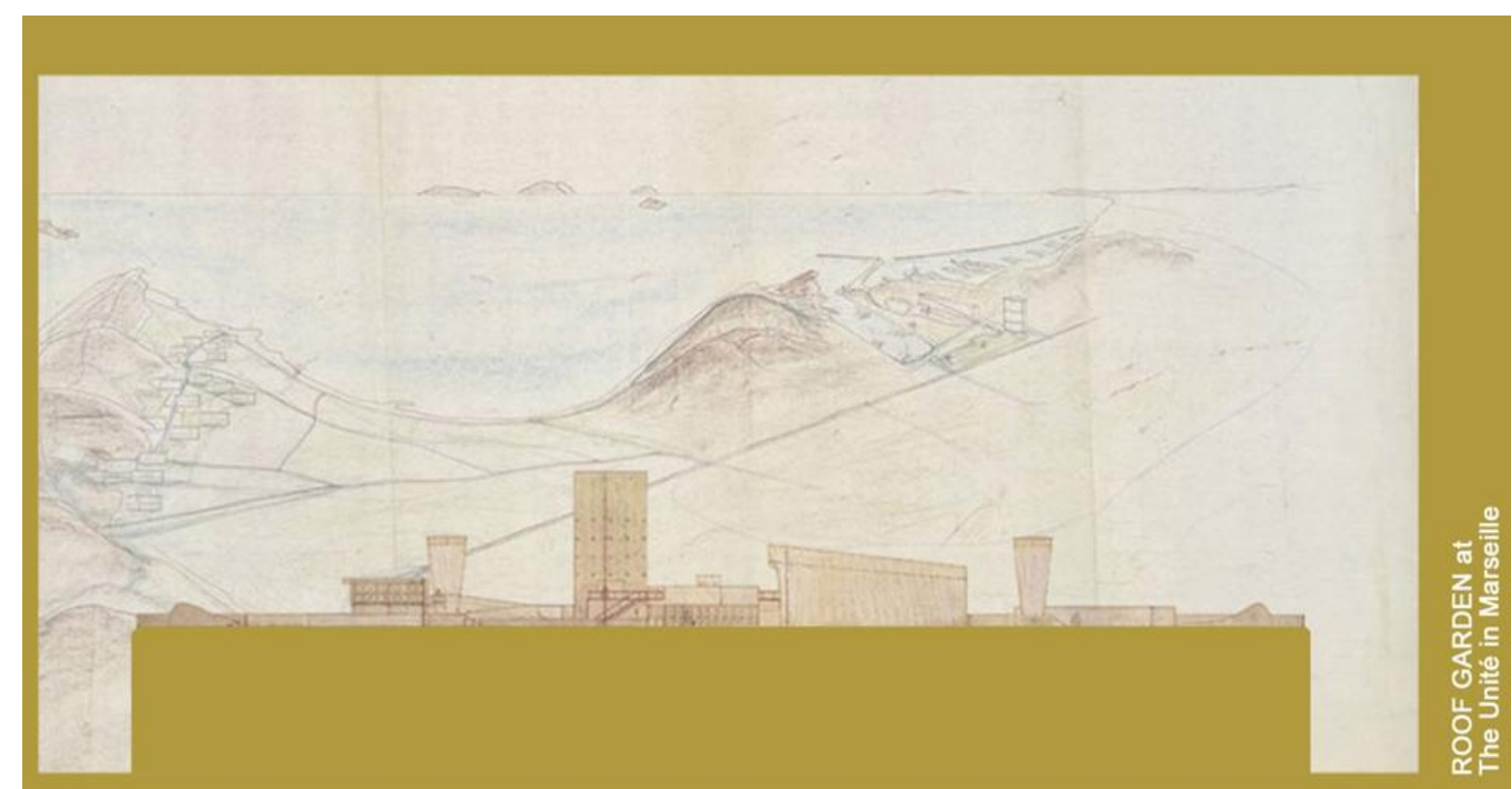

15. Collage by the authors.

Within the space Le Corbusier dedicated to writing about this complex and fundamental oeuvre - the Unité - in the $5^{\text {th }}$ volume of the Complete Works - (published when the building had just been completed) - the description of its roof space, is very notable ${ }^{28}$. It immediately strikes the reader that here there are no traces of untamed nature, nor any attempt to insulate and protect the béton from expansion and contraction, nor walls shielding against the city. Here Le Corbusier opens his research to new design and artistic experimentations.

Both in the Complete Works text and through the famous photomontage, the Unite roof space is described as an autonomous element, detached from the remainder of the building. It is as the whole building is nothing other than a powerful substructure for the dominating horizontal plane and articulated set of forms placed on top, all immersed within the profile of the horizon.

This corresponds to Le Corbusier Acropolis description in his travelling sketches. When the writing "Architecture is the correct and magnificent play of masses brought together in light" ${ }^{29}$ is placed alongside one of the photographs of the Marseille roof, on the Complete Works, there is a direct parallel between this oeuvre and the celebrated reference of Vers une architetture.$^{30}$

The Marseille roof is, at the same time, the manifestation of an idea, a model which takes shape, and a prototype of subsequent developments. It is a "city within the city" 31 , a complex and dense space, dense for both functional programme and compositional strategies.

28 "L’Unité d'Habitation in Marseille". In Le Corbusier: Oeuvre complète 1946-1952. Volume 5. Boesiger Willy (Ed.). Zurich: Girsberger, 1985. 8th ed. pp.189-223.

${ }^{29}$ Ibid. p.222.

${ }^{30}$ Le Corbusier: Vers une architetture. Paris: G. Crès \& Cie, 1923.

${ }^{31}$ Moos, Stanislaus von: "Machine et nature: notes à propos de l'Unité d'habitation de Marseille". In Prelorenzo, Claude (Ed.): Le Corbusier. La Nature. Paris: Éditions de la Villette, 2005. pp. 43-54. 
Le Corbusier organises the roof-garden with one part reserved for the children with a small pool connected directly with a nursery and a primary school at the lower level, and with a gymnasium, a gathering space for open-air exercise, a solarium, a 300 m running track, buffet-bar, and service elements.

This roof is the public space par excellence of Le Corbusier's vertical village: a pedestrian elevated square at 56 $\mathrm{m}$ off the ground, a vast open space uncommonly elongated - 164 × $24 \mathrm{~m}$, conceived as a space for both body and spirit.

It is a garden suspended in the sky: a stone garden inhabited by a variety and fragmented set of forms rigorously in béton armé, where Le Corbusier adopts organic and plastic shapes inspired by botany and nature, in stark contrast to the rigorous and stereometric geometry of the housing block.

Ultimately this is a belvedere stretching toward its splendid horizon, a place for contemplation and meditation: "Up above, at $56 \mathrm{~m}$ from the ground, there's the most impressive and moving view of the world: the sea and the islands, the mountain range of Saint Cyr and the Tete of Puget, the Sainte-Baume, the mountain of SaincteVictorie, Marseille-la-Ville and Notre-Dame-de-le-Garde, l'Estaque. [...] This roof will be part of the landscape of Marseille. Its outline must be eloquent, a varied and soft discourse". ${ }^{32}$

The Unité roof-garden is a public space recalling suggestions of the Pompeii Forum and the Athens Acropolis, as well as the upper deck of an ocean liner.

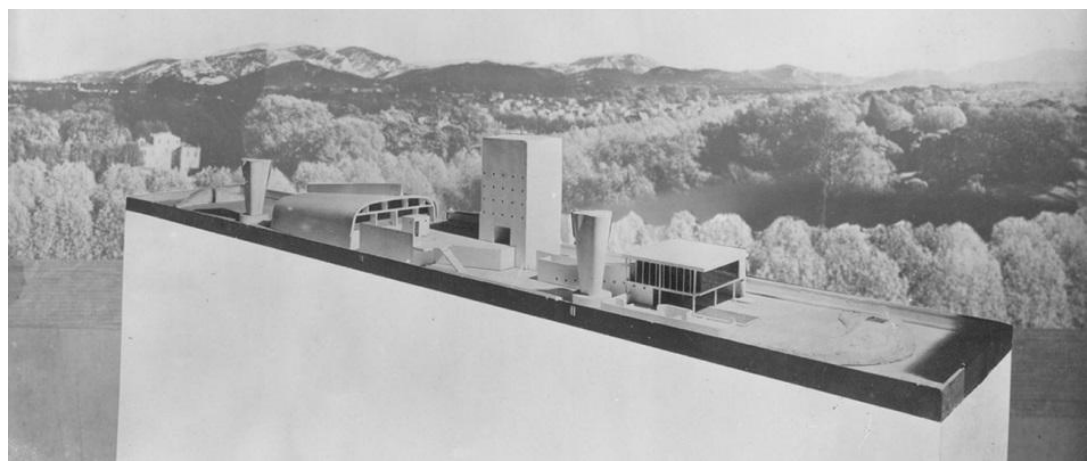

16. View of the model of the roof terrace in the Unite d'Habitation in Marseille.

\subsection{Composing sequences on the horizon line}

Buildings, plastic forms, open-air spaces are all composed in an intense dialogue with the line of the horizon. The parapet is solid and high, signed by the projection of the crowning corbel just below the eye level $(1,60 \mathrm{~m})$ : it restrains rather and doesn't invite you to look out, only narrow gaps, at structural joints, permit any view. Along the whole perimeter, the running track runs steady, without start or end points. Like a rut, it separates and distances the plastic composition from the urban surroundings. The main architectural elements are all gathered on the central platform, where vision reads the forms in a direct and dynamic relation with the mountains, sea and sky. As is for the Acropolis, "The equilibrium [...] is determined by the famous landscape which stretches

\footnotetext{
${ }^{32}$ Le Corbusier: Il Modulor + Modulor 2. Saggio su una misura armonica a scala umana universalmente applicabile all'architettura e alla meccanica. Saurwein, Emanuele (Ed). Mendrisio: Gabriele Cappelli editore, 2004. Volume "Il Modulor". p. 150.
} 
from the Piraeus to Mount Pentelicus". ${ }^{33}$ So too, on this roof terrace, it is the impressive horizon, with the sea, hills and islands, that influences the arrangement and shaping of component structures.

The main buildings -gymnasium, lift tower with water tank, and nursery - are in the centre of the platform, creating an outdoor tripartition of this city fragment. The first and central area, gathers all access to the terrace, with ramp and lifts, and is open to the view of the sea and the far away islands on the West side. The second, the children's garden on the South side, is oriented toward the view of the beautiful mountains; the third is fitness platform on the North side, almost isolated by the gymnasium, and faces the port of the Joliette.
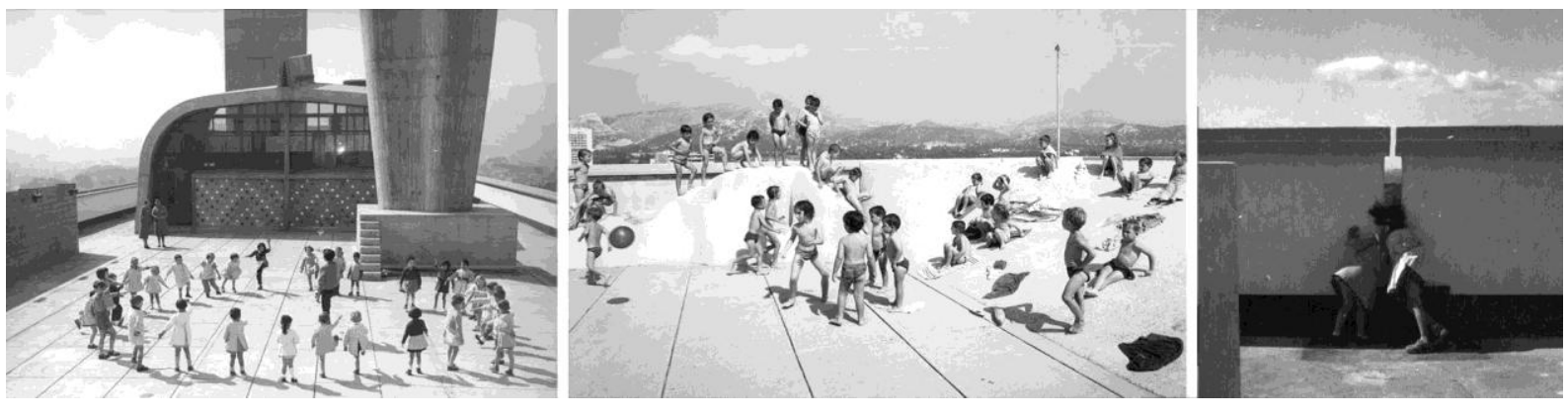

17. Roof terrace at the Unité d'Habitation in Marseille.

On the Marseille belvedere the composition envisages, that rather than have continuous boundary edges, it is defined by obstacles, accents and pauses, all capable of interacting with the horizon. These features include an inclined wall, windbreaks walls, a remarkably long and deep flower box and a funnel shaped ventilation stack which rather than cutting out or framing the landscape, takes on a dialectic relation with the natural elements.

The articulated profile of the mountains and the rectilinear profile of sea become the materials of the project. Where "the space is too vast, or the horizon isn't interesting, a wall is created on the right, three steps down there. From now on the theatre festivals can happen here, in summer, without the need of an additional scene". ${ }^{34}$ At the other end, where the horizon line is rich and indented (toward south), the symphony of forms reach the "biggest intensity at the most essential point (which is at the base of the mountains on the horizon)", 35

On this side, the articulated composition of pure volumes and plastic forms, together with the partitions of the children's garden, is always kept within the height of the solid parapet. The only emerging element is a column shaft, which offers an additional reference to the Acropolis. The powerful inclined plane - separating the children's garden from the running track - links the paving to the horizontal line of the parapet, and thus becomes the base to the mountains setting.

\footnotetext{
${ }^{33}$ Le Corbusier: Verso una architettura. Cerri, Pierluigi; Nicolin, Pierluigi (Eds.). Milano: Longanesi \&C, 1989. p. 39

34 “L’Unité d'Habitation in Marseille”, op. cit. p. 222. Authors' translation.

${ }^{35}$ Ibid. p. 221. Authors' translation.
} 

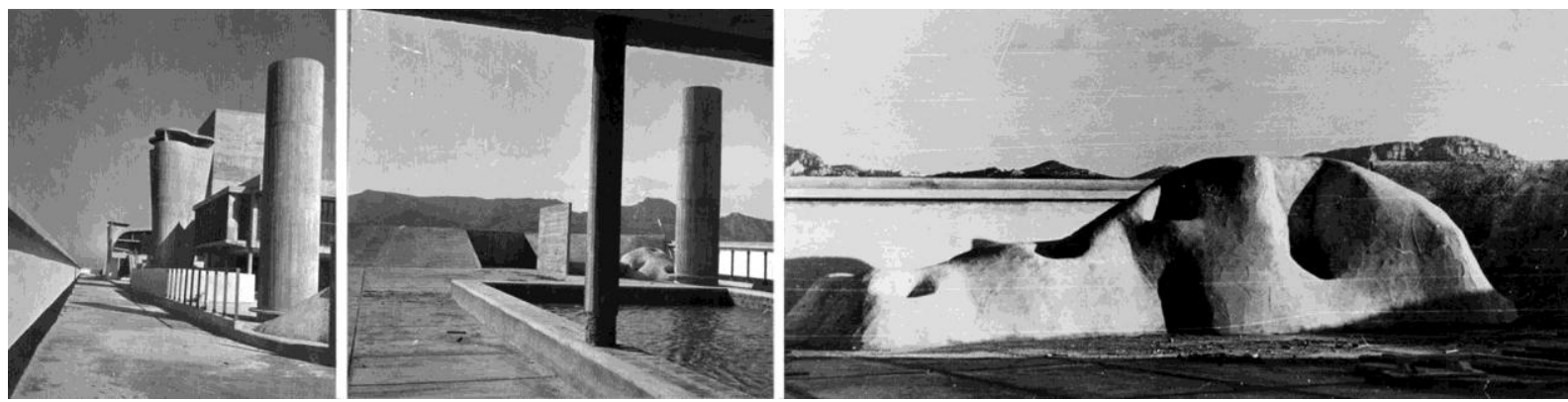

18. Roof terrace at the Unité d'Habitation in Marseille.

The compositional strategy adopted by Le Corbusier in this particular area of the roof garden, rather than recall the Parisian Beistegui Attic, seems to anticipate his visions for Chandigarh, India. Using the solution of the boundary banks around the Capitol- with a technique analogous to a cinematographical montage - the middle ground is removed from view and the foreground becomes directly connected to the background. ${ }^{36}$

The stone roof garden of Marseille, again as with the Acropolis, and this time through the reading of Eisenstein ${ }^{37}$, "turns the inhabitant of space into a consumer of views". "38 "In my work I have the impression of thinking as Eisenstein does in his films" affirms Le Corbusier", who also writes in his notepad: "invite a film maker onto Marseille roof; extraordinary".

The varied fragments are constructed into a coherent whole, through the succession of the views, which one experiences within the experience of the site. Not univocally connected with a pre-definite path, as it happens somewhere else with the promenade architecturale, the succession is here left to the free choice of the stroller. It is perhaps for this reason that, as a director in the montage work, Le Corbusier feels the need of marking down in his notepad: "to envisage a touristic circuit with various strategic points (the visitor should not interrupt but to look from a point of view) exercise / restaurant / nursery / children clubs / hall". ${ }^{40}$

\subsection{The Marseille roof-terrace Nature}

Architectural artefacts, and protective structural elements are variously sculptured in béton before being assembled and juxtaposed. They become the occasion to celebrate a plasticity in composition, a symphony of forms, which as for his sculptures carry a kind of "acoustic nature - that projects far the effect of their forms and, conversely also receive the pressure of the surrounding spaces". 41

The whole set is very fragmented but articulated: pure prisms pulled together with organic forms evoking the natural world, whilst others return to the metaphor of the ocean liner - chimneys for ventilation, a boat keel for the gymnasium roof. For all of these, one unique material béton brut is chosen which, according to Le Corbusier

\footnotetext{
${ }^{36}$ Costant, Carolin: "From the Virgilian Dream to Chandigarh: Le Corbusier and the Modern Landscape". In Wrede, Stuart; Adams, William Hower (Eds.): Denatured Vision. Lanscape and culture in the twentieth century. New York: The Museum of Modern Art, 1991. pp 79-93.

37 "Metropolitan Montage. The City as Film in Kracauer, Benjamin, and Eisenstein". In Vidler, Anthony: Warped Space. Art, Architecture, and Anxiety in Modern Culture. Cambridge Mass.: The MIT Press, 2000. pp. 111-122 .

${ }^{38}$ Bruno, Giuliana: Atlas of Emotion, op. cit. p. 58.

${ }^{39}$ Cohen, Jean-Louis: Le Corbusier and the Mystique of the USSR. Princeton: Princeton University Press, 1992. p. 49.

${ }^{40}$ Le Corbusier: Carnet vol IV. Paris: Herscher, Dessain et Tolra, 1981. p. 295.

41 “Le Corbusier et Savina”. In Le Corbusier: Oeuvre complète 1946-1952. Volume 5, op. cit. p. 240. Authors' translation.
} 
is "a natural material of the same rank as stone, wood or terracotta"42 and reveals infinite expressive potentialities, such that the Unité could be regarded as a treatise on reinforced concrete. ${ }^{43}$

Any fault, or blemish in the concrete, is considered natural because it is human, it is an expressive opportunity so there is no attempt to correct or conceal it: "I will find its complement and establish a play between crudity and finesse, between the dull and the intense, between precision and accident. [...] Exposed concrete shows the least incidents of the shuttering, the joint of the planks, the fibres and knots of the wood, etc. But these are magnificent to look at, they are interesting to observe, to those who have a little of imagination they add a certain richness" ${ }^{\prime 4}$.

This imaginative capability is revealed by Le Corbusier when filming on the shores of Arcachon and Rio. Le Corbusier repeatedly films, again and again, the artefacts which capture his attention on the shore - shells, branches, fossils and traces stamped on the sand, with a rich texture and intricacy of reliefs, randomly produced by the sea and the sand. The camera zooms on the fragments, detaches them from their context, then offers up casts, concretions, sculptural oeuvres; it catches their visual and tactile qualities, marking them down in Le Corbusier poetic imaginary, to later reveal them in the plastic oeuvres. The films recapture Le Corbusier observations on the natural and urban landscape and reveal sources for his inspiration.

Nature - in the sense of the natural and untamed, of the grass and wild flowers - is completely absent on this roof, except for few paltry details of flower boxes and artificial mounds, originally designed in grass and plants, but actually built in beton brut. Nature, though, returns powerfully in these string objects à reaction poetique.

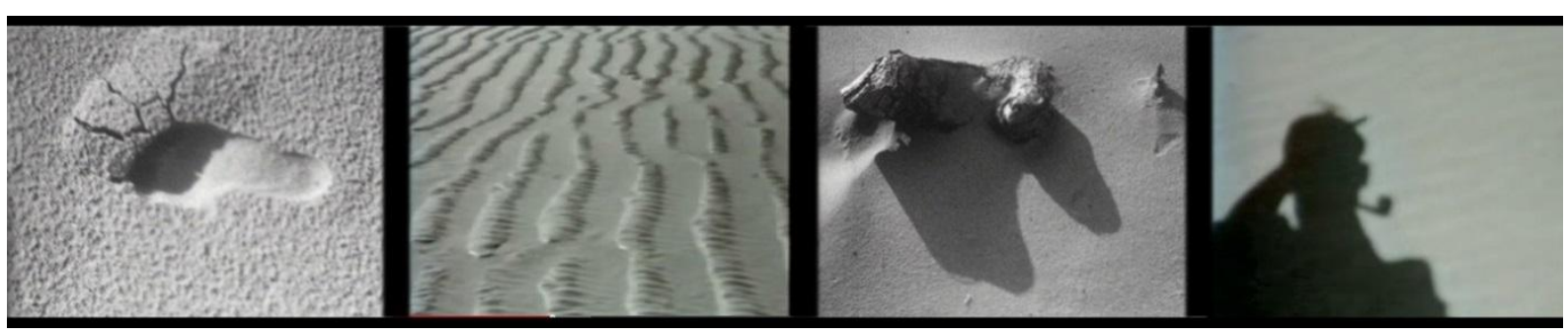

19. Stills from Le Corbusier 1936-38 film. Montage by the authors.

\section{Visions}

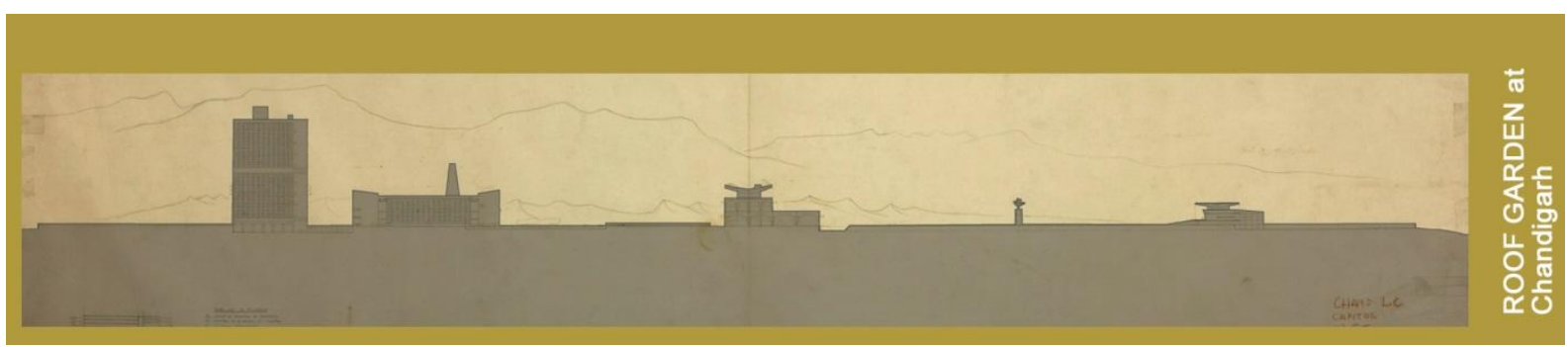

20. Collage by the authors.

\footnotetext{
42 “L’Unité d'Habitation in Marseille”, op. cit. p. 191.

${ }^{43}$ Von Moos, Stanislaus: "Machine et nature: notes à propos de l'Unité d'habitation de Marseille", op. cit.

44 “L’Unité d'Habitation in Marseille”, op. cit. p. 191.
} 
Within the technical evolutions related to the new material of reinforced concrete, Le Corbusier was able to discover new potential for the space of the roof garden and for the architecture and the modern city, developing it from the domestic to an urban scale. Both in rue Nungesser-et-Coli and at the Unité, Le Corbusier outlined the coordinates of contemporary research onto the urban landscape.

From the urban dimension of the Marseille solution, the roof-garden topic finds a territorial measure in Chandigarh. Because of the climate, the roof, together with the brise-soleil, becomes the characterizing theme for both the building and its overall setting. The roof is developed in a variety of ways so that we find the roofbasin, the roof-hat, the roof-terrace, the roof-garden. Here, where all is roof, Le Corbusier feels the need to represent the ground and the articulated outlines of the buildings as part of a single body offered to the horizon of the Himalayas. A continuous trace describes the unified profile of the buildings, it descends to the ground and excavates hollows and banks, or it raises hills, platforms, and podiums in order to articulate the strong horizontal definition of the plain.

The relationship with nature acquires a new cosmic dimension: the sun, the stars, the earth, the rain, the wind, are now primary forces shaping the architecture volumes, they pass through them and fill them, giving meaning to their forms.

Visionary and forward-looking, the view of Le Corbusier on the city and its landscape, from the high perspective of his roofs-gardens, still appears rich in suggestions today.

His ideas about nature in the natural state that were introduced on the roof garden in rue Nungesser-et-Coli and in Villa Le Lac, intertwine strong relations with the studies of the landscape by Gilles Clement - the third landscape, the moving garden and the untamed. Le Corbusier's concept of the roof garden as an urban public space is now being adopted in many roof- top projects all over the world, transforming the urban landscape and modernising traditional ideas of the city. The upper parts of buildings are being transformed into public squares or sky gardens, testifying the collective need to rediscover a direct relationship with nature within the big cities, starting from the roofs.

\section{Acknowledgements}

Fondation Le Corbusier, for support.

\section{Source of images}

Courtesy Fondation Le Corbusier:

FLC Plan 31514: 11.a; FLC Plan 18758: 11.d; FLC L1(10)46: 12.d; FLC L1(12)38: 16; FLC L1(15)103: 18.c; stills from Le Corbusier films «Films de Le Corbusier» (C) FLC-ADAGP: 3.b; 5; 6; 8.

Photograph by Henri-Paul Boissonnas, (C) Bibliothèque de Genève: FLC L3(18)48: 13.a.

Photograph by Marius Car: FLC L2(19)15: 11.c.

Photograph by Charles Gérard: FLC L1(6)11: 12.a; FLC L2(15)55: 11.b.

Photograph by Lucien Hervé: (C J. Paul Getty Trust. The Getty Research Institute, Los Angeles (2002.R.41):

FLC L2(10)135: 3.left; FLC L3(8)134-23: 14.a; FLC L3(8)137-51: 14.b; FLC L3(8)36-119: 14.c; FLC L3(9)42131: 14.d; FLC L2(1)34-184: 17.c; FLC L2(1)32-167: 18.a; FLC L2(1)59-643: 18.b.

Photograph by Dr Losen \& Co: FLC L1(2)67: 12.c.

Photograph by Melle Meyer: FLC L3(17)138: 9.

Photograph by Moiroud, FLC L4(2)6: 2.a. 
Photograph by Louis Sciarli: FLC L1(11)1: 17.a; FLC L1(11)42: 17.b.

Photograph by Peter Willi: FLC L2(17)42: 12.b.

Extract from Le Corbusier: Oeuvre complète 1910-29. Volume 1. W. Boesiger (Ed.). Zurich: Girsberger, 1984. 11th ed. p.182, (Immeuble Wanner): 13.c.

Extract from Le Corbusier: Oeuvre complète 1952-1957. Volume 6. W. Boesiger (Ed.). Zurich: Girsberger, 1985. 7th ed. p.50: 2.b.

Stills from Architecture d'Aujourd'hui. Directed by Pierre Chenal. Script by Pierre Chenal and Le Corbusier. Texts by Le Corbusier. Music by Albert Jeanneret. Produced by the review Architecture d'Aujourd'hui, 35 mm, b\&w, time 18 min. 1930: 13.b; 13.d.

Still from Le Corbusier. Film by Barsac, Jacques. Produced by Barsac, Jacques and Archambeaud, Christian. Distributed by Cine Service Technique, Film in 3 parts, 176 min., 1987: 19.

\section{Bibliography}

Le Corbusier: Vers une architetture. Paris: G. Crès \& Cie, 1923. Italian edition: Le Corbusier: Verso una architettura. Cerri, Pierluigi; Nicolin, Pierluigi (Eds.). Milano: Longanesi \&C, 1989.

L'Art décoratif d'aujourd'hui. Paris: G. Crès \& Cie, 1925.

Une Petit Maison 1923. Zurich: Aux Édition d'Architecture, 1954.

Carnet vol IV. Paris: Herscher, Dessain et Tolra, 1981.

Oeuvre complète. Boesiger, Willy (Ed.), vols. 1, 2, 4-8; Bill, Max (Ed.), vol. 3. Zurich: Girsberger, 1977, $1984-$ 1986.

“L’Arc-de-Triomphe a bruciapelo”. In Casabella, January/February 1987, N 531/532. Milano: Electa.

Il Modulor + Modulor 2. Saggio su una misura armonica a scala umana universalmente applicabile all'architettura e alla meccanica. Saurwein, Emanuele (Ed). Mendrisio: Gabriele Cappelli editore, 2004.

Brooks, H. Allen (Ed.): Le Corbusier. Princeton: Princeton University Press, 1987.

Bruno, Giuliana: Atlas of Emotion: Journeys in Art, Architecture, and Film. New York: Verso Books, 2007.

Cohen, Jean-Louis: Le Corbusier and the Mystique of the USSR. Princeton: Princeton University Press, 1992.

Le Corbusier. Le Grand. New York: Phaidon Press Limited, 2014.

Costant, Carolin: "From the Virgilian Dream to Chandigarh: Le Corbusier and the Modern Landscape". In

Reichlin, Bruno: “L’Esprit de Paris”. In Casabella. January/February 1987, N 531/532. Milano: Electa. pp. $52-$ 55 .

Moos, Stanislaus von: "Machine et nature: notes à propos de l'Unité d'habitation de Marseille". In Prelorenzo, Claude (Ed): Le Corbusier. La Nature. Paris: Éditions de la Villette, 2005.

Sbriglio, Jacques : Le Corbusier. Aventures photographiques. Paris: Éditions de la Villette, 2014.

Vidler, Anthony: Warped Space. Art, Architecture, and Anxiety in Modern Culture. Cambridge Mass.: The MIT Press, 2000.

Wrede, Stuart; Adam, William Hower (Eds.): Denatured Vision. Lanscape and culture in the twentieth century. New York: The Museum of Modern Art, 1991.

Films:

«Films de Le Corbusier» (C FLC-ADAGP. Paris: Fondation Le Corbusier. 
Architecture d'Aujourd'hui. Film directed by Pierre Chenal. Script by Pierre Chenal and Le Corbusier. Texts by Le Corbusier. Music by Albert Jeanneret. Produced by the review Architecture d'Aujourd'hui, $35 \mathrm{~mm}$, b\&w, time 18 min. 1930.

Le Corbusier. Film by Barsac, Jacques. Produced by Barsac, Jacques and Archambeaud, Christian. Distributed by Cine Service Technique, Film in 3 parts, 176 min., 1987. 